\title{
Pearls \& Oy-sters: SARS-CoV-2 Infection of the CNS in a Patient With Meningeosis Carcinomatosa
}

Philipp A. Steininger, MD, Frank Seifert, MD, Stefanie Balk, MD, Joji Kuramatsu, MD, Andreas E. Kremer, MD, PhD, Roland Coras, MD, Tobias Engelhorn, MD, Clara Maier, Matthias Tenbusch, PhD, Klaus Korn, MD, and Armin Ensser, MD

Neurology ${ }^{\circledR}$ 2021;96:496-499. doi:10.1212/WNL.0000000000011357

\section{Pearls}

- Neurologic severe acute respiratory syndrome coronavirus 2 (SARS-CoV-2) infection can present with fever, headache, and meningism.

- For diagnosis of SARS-CoV-2 infection of the CNS, reverse transcription PCR (RT-PCR) from CSF samples should be performed, because viral RNA may be detected in CSF for longer periods than in respiratory samples.

- Determination of the SARS-CoV-2-specific immunoglobulin G (IgG) antibody index in CSF and serum is feasible for the detection of a SARS-CoV-2-specific intrathecal IgG antibody synthesis.

\section{Oy-sters}

- Neurologic SARS-CoV-2 disease can present without accessory respiratory symptoms and signs.

- Negative SARS-CoV-2 RT-PCR in respiratory specimens does not exclude SARS-CoV-2 infection of the CNS.

- In patients with meningeosis neoplastica presenting with acute neurologic symptoms, the possibility of concomitant CNS infection should always be considered.

Coronavirus disease 2019 (COVID-19), the disease caused by SARS-CoV-2, primarily manifests as respiratory illness. Disease severity ranges from asymptomatic infections to acute respiratory distress syndrome. Recent observations demonstrated that SARS-CoV-2 can also cause neurologic symptoms, which is known for many coronaviruses, including SARS-CoV-1 and Middle East respiratory syndrome coronavirus. ${ }^{1}$ Risk factors for neurologic complications of COVID-19, clinical presentation, and the appropriate virologic diagnostic approach need to be further analyzed. We report a case of SARS-CoV-2 infection of the CNS in a patient with meningeosis carcinomatosa.

\section{Case Presentation}

A 53-year-old man was transferred to our hospital (day 1) with fever and increasing headache for 1 day. The day before admission, a nasopharyngeal swab was positive for SARS-CoV-2 RNA. The patient reported no respiratory symptoms. Due to suspected meningitis, an empirical anti-infective treatment consisting of ceftriaxone, ampicillin, and acyclovir was immediately initiated. Adenocarcinoma of the esophagus (ypT1bpN2M0R0) had been diagnosed 4 months earlier, which was resected after 4 cycles of neoadjuvant chemotherapy with the FLOT regimen (folinic acid, 5-fluoruracil, oxaliplatin, docetaxel). At neurologic examination, the patient presented with meningism and decreased vigilance. The patient did not show any signs

\section{Correspondence}

Dr. Steininger

philipp.steininger@

uk-erlangen.de

MORE ONLINE

COVID-19 Resources

For the latest articles, invited commentaries, and blogs from physicians around the world

NPub.org/COVID19

From the Institute of Clinical and Molecular Virology (P.A.S., C.M., M.T., K.K., A.E.) and Departments of Neurology (F.S., S.B., J.K.), Medicine 1 (A.E.K.), Neuropathology (R.C.), and Neuroradiology (T.E.), University Hospital of Erlangen, Friedrich-Alexander University Erlangen-Nürnberg, Germany.

Go to Neurology.org/N for full disclosures. Funding information and disclosures deemed relevant by the authors, if any, are provided at the end of the article. 
of a respiratory infection. Respiratory rate was 12 breaths per minute and oxygen saturation was $96 \%$ without additional oxygen supply. Differential blood count showed leukocytopenia $(2.88 / \mathrm{nL})$ and normal neutrophil granulocyte count $(2.46 / \mathrm{nL})$ and absolute lymphocytopenia $(0.34 / \mathrm{nL})$. Together with normal C-reactive protein $(2.8 \mathrm{mg} / \mathrm{L})$, these laboratory findings were suggestive for a viral infection. CSF analysis on day 1 revealed lymphomonocytic pleocytosis $(57$ leukocytes $/ \mu \mathrm{L}, 96.5 \%$ mononuclear cells; 3 red blood cells/ $\mu \mathrm{L})$ with elevated lactate $(5.84 \mathrm{mmol} / \mathrm{L})$ and protein levels $(1,363 \mathrm{mg} / \mathrm{L})$, while glucose level was highly decreased (12 $\mathrm{mg} / \mathrm{dL}$ ). Neuropathologic cytologic analysis of the CSF demonstrated malignant epithelial cells (expressing the epithelial membrane antigen) in terms of a meningeosis neoplastica. MRI of the brain on day 4 revealed several infratentorial and supratentorial lesions (figure, A). This was suggestive for cerebral metastasis of the esophageal carcinoma. CT scan of the chest and abdomen on day 6 showed partial atelectasis of the pulmonary right lower lobe and typical postoperative changes with reactively enlarged mediastinal lymph nodes. There was evidence of neither COVID-19 pneumonia nor for local recurrence of the adenocarcinoma or further organ metastases.

Microbiological culture and a universal bacterial 16S-rDNA PCR were negative in the CSF sample from day 2. Because a nasopharyngeal swab was positive for SARS-CoV-2 RNA 1 day before admission to our hospital, further diagnostics for SARS-CoV-2 was initiated. Real-time RT-PCR analyses, using an in-house method targeting the SARS-CoV-2 E gene (screening assay) and the RdRp gene (confirmatory assay), were performed according to a previously published protocol. ${ }^{2}$ On day 2, both screening and confirmatory assay were positive for SARS-CoV-2 RNA in the CSF (cycle threshold [ct] 19.5 and 21.6, respectively) and in the serum sample (ct 28.8 and 32.9, respectively), while PCR analysis of a nasopharyngeal swab was negative on day 5 . Seroconversion was detected by an in-house fluorescence-activated cell sorting (FACS) antibody assay, using the SARS-CoV-2 full-length S protein, for immunoglobulin $\mathrm{M}$ ( $(\mathrm{gMM})$ antibodies on day 2

Figure MRI and Fluorescence-Activated Cell Sorting (FACS)-Based Quantitative Measurement

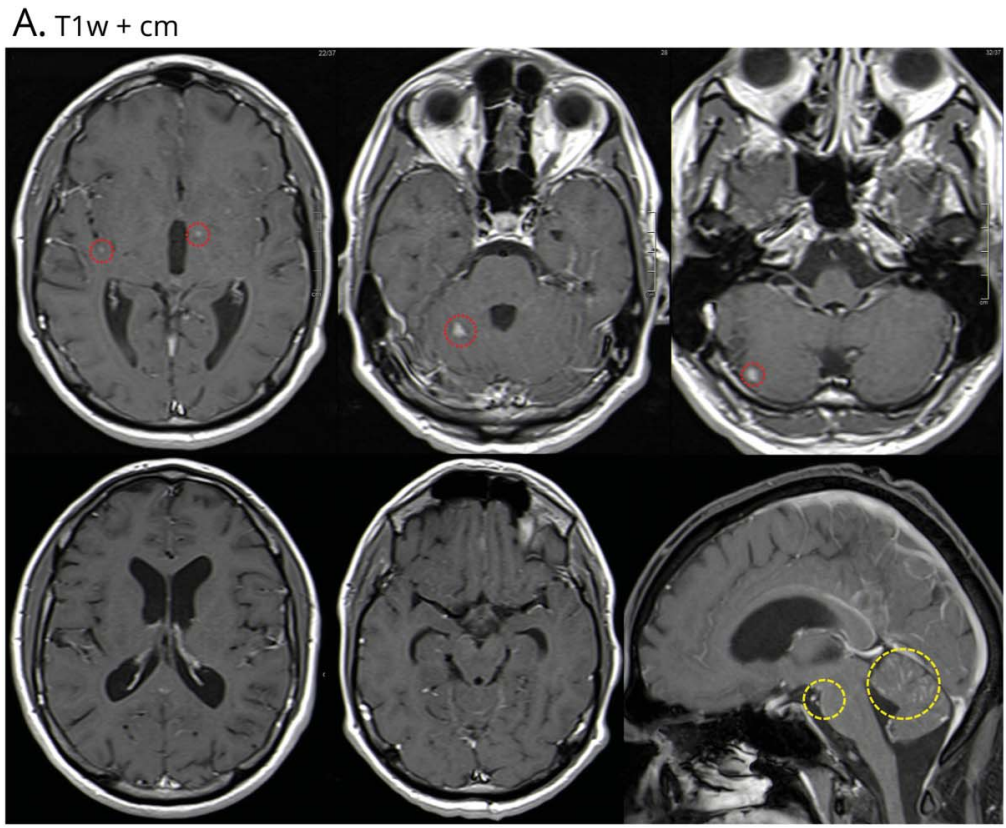

B

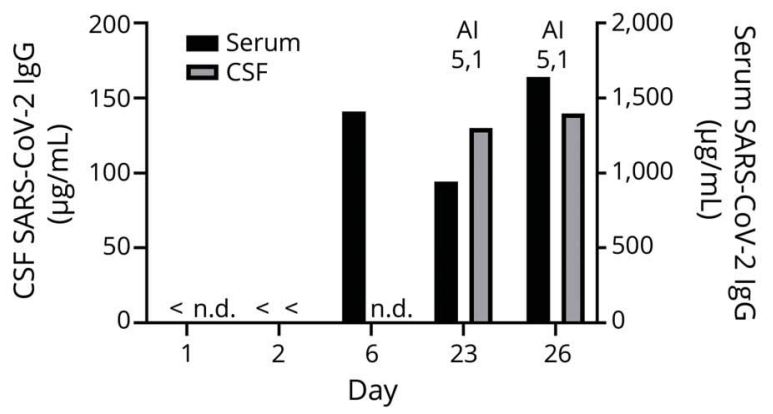

(A) MRI of the brain on day 4. Upper row: axial T1-weighted MRI after IV contrast media application revealed 2 supratentorial and 2 infratentorial parenchymal lesions with slight perifocal edema (red circles). With regard to the adenocarcinoma of the esophagus, these lesions were suggestive for cerebral metastasis of the esophageal carcinoma. Lower row (left and middle): axial T1-weighted MRI after IV contrast media application demonstrated slight generalized atrophy of the brain with subsequent slightly enlarged sulci and ventricles without clear signs of a hydrocephalus referring in particular to the temporal horns. Lower row (right): sagittal T1-weighted MRI after IV contrast media application demonstrated infratentorial leptomeningeal thickening and increased contrast enhancement (yellow circles). (B) FACSbased quantitative measurement of severe acute respiratory syndrome coronavirus 2 (SARS-CoV-2)-specific immunoglobulin G (IgG) antibodies in serum and CSF. Seroconversion for SARS-CoV-2 IgG was detected on day 6 . The SARS-CoV-2 IgG CSF/serum ratio for paired CSF/serum samples on day 23 and day 26 was $140 \times 10^{-3}$ and $90 \times 10^{-3}$, respectively. Based on total IgG and albumin values for CSF' and serum, the SARS-CoV-2 IgG specific antibody index (AI) was 5.1 for both pairs. This verified a SARS-CoV-2-specific intrathecal IgG antibody synthesis. <= under detection limit; n.d. $=$ not determined. 
and for IgG antibodies on day 6, verifying an acute SARSCoV-2 infection. ${ }^{3}$ Furthermore, IgM (not shown) and IgG antibodies to SARS-CoV-2 were also detected in CSF from day 23 and 26 (figure, B). Clinically, there was a significant reduction of the headache on day 3. In follow-up PCR analyses, SARS-CoV-2 RNA was detected in low concentration in a CSF sample on day 20 (ct value 33.9), whereas the last 2 CSF and serum samples obtained on day 23 and day 26 were PCR-negative.

Determination of the SARS-CoV-2-specific IgG antibody indices (AIs) for these $2 \mathrm{CSF} /$ serum pairs was performed by using the FACS antibody assay for quantitation of SARSCoV-2 IgG antibodies and kinetic nephelometry for measurement of total IgG concentrations in CSF and serum. The SARS-CoV-2 IgG CSF/serum ratios were $140 \times 10^{-3}$ and 90 $\times 10^{-3}$ on day 23 and day 26 , respectively. In comparison, the total IgG quotients were only $27.7 \times 10^{-3}$ and $17.6 \times 10^{-3}$ for the $2 \mathrm{CSF} /$ serum pairs. The SARS-CoV-2 IgG-specific AI, calculated by dividing the pathogen-specific IgG quotient by the total IgG quotient, ${ }^{4}$ was 5.1 for both pairs. In cases without pathogen-specific intrathecal antibody synthesis, the AI is expected to be 1.0 (range $0.5-1.5$ ). Thus, the elevated AI of 5.1 in $2 \mathrm{CSF} /$ serum pairs of this patient, 5 times higher than expected from IgG diffusion across the blood-brain barrier, demonstrated intrathecal antibody synthesis. This is an additional indicator for active or past SARS-CoV-2 replication in the CNS compartment.

Later in the course of disease, after elimination of the virus, intrathecal chemotherapy and radiotherapy were initiated due to progression of the cerebral metastases.

\section{Discussion}

Our report describes the first case of SARS-CoV-2 meningitis in a patient with meningeosis carcinomatosa. SARS-CoV-2 infection of the CNS was confirmed by detection of viral RNA in 2 independent CSF samples and SARS-CoV-2-specific intrathecal IgG antibody synthesis.

There is increasing awareness for the neurotropic potential of SARS-CoV-2, yet the exact mechanism for entry in the CNS is unknown. Infection via the olfactory epithelium and nerve or hematogenous infection by viremia are currently discussed routes for neuroinvasion. ${ }^{5}$ Meningeosis carcinomatosa might enhance the neuroinvasiveness of SARS-CoV-2 by increasing the permeability of the blood-brain barrier, or might allow spread of virus from the brain into hematogenous circulation. From a pathophysiologic perspective, the latter mechanism might be more likely in our patient. First, on day 2 the viral RNA concentration in CSF was more than 100-fold higher than in serum, verifying autochthonous virus replication within the CNS compartment. Second, detection of SARS-CoV-2 RNA in the blood is usually considered as a virologic marker for severe pulmonary or systemic disease, ${ }^{6}$ but our patient did not present with severe respiratory or other extraneurologic symptoms.

SARS-CoV-2 infection of the CNS was also reported in an apparently immunocompetent patient. ${ }^{7}$ Therefore, it remains unclear whether neoplastic meningitis and immunosuppression are relevant risk factors for a neuroinvasive SARS-CoV-2 infection, or if both conditions appeared coincidentally in our patient without a pathophysiologic link. A limitation in the attribution of the patient's headache as a neurologic manifestation of COVID-19 is that this symptom could be also caused by the meningeosis carcinomatosa or cerebral metastasis. However, there was a significant improvement of the headache on day 3 , which correlated with the beginning of the adaptive immune response of the patient, since IgM antibody seroconversion was detected on day 2 . In addition, neither an antiedematous nor antineoplastic therapy was administered at that time.

Our case demonstrates that in patients with neurologic symptoms, PCR diagnosis for SARS-CoV-2 RNA from both respiratory and CSF specimen is required. In the course of neurologic SARS-CoV-2 disease, viral RNA might be undetectable in respiratory samples, while SARS-CoV-2 RNA can be detected in CSF for longer periods, in our case for 18 days. In addition, the detection of seroconversion and quantitation of SARS-CoV-2-specific antibodies in CSF and serum can contribute to the diagnosis of COVID-19-associated neurologic involvement.

\section{Study Funding}

The authors report no targeted funding.

\section{Disclosure}

The authors report no disclosures relevant to the manuscript. Go to Neurology.org/ $\mathrm{N}$ for full disclosures.

\section{Appendix Authors}

\begin{tabular}{lll}
\hline Name & Location & Contribution \\
\hline $\begin{array}{l}\text { Philipp A. } \\
\text { MD }\end{array}$ & $\begin{array}{l}\text { University Hospital } \\
\text { of Erlangen, } \\
\text { Germany }\end{array}$ & $\begin{array}{l}\text { Conceptualized case, wrote the } \\
\text { manuscript, performed the } \\
\text { molecular diagnostics, } \\
\text { interpreted data }\end{array}$ \\
\hline $\begin{array}{l}\text { Frank Seifert, } \\
\text { MD }\end{array}$ & $\begin{array}{l}\text { University Hospital } \\
\text { of Erlangen, } \\
\text { Germany }\end{array}$ & $\begin{array}{l}\text { Treated the patient, collection of } \\
\text { patient samples, reviewed the } \\
\text { final manuscript }\end{array}$ \\
$\begin{array}{l}\text { Stefanie } \\
\text { Balk, MD }\end{array}$ & $\begin{array}{l}\text { University Hospital } \\
\text { of Erlangen, } \\
\text { Germany }\end{array}$ & $\begin{array}{l}\text { Treated the patient, data } \\
\text { acquisition, reviewed the final } \\
\text { manuscript }\end{array}$ \\
$\begin{array}{lll}\text { Joji } \\
\text { Kuramatsu, } \\
\text { MD }\end{array}$ & $\begin{array}{l}\text { University Hospital } \\
\text { of Erlangen, }\end{array}$ & $\begin{array}{l}\text { Treated the patient, reviewed the } \\
\text { final manuscript }\end{array}$ \\
\hline $\begin{array}{l}\text { Germany } \\
\text { Kremer, MD, } \\
\text { PhD }\end{array}$ & $\begin{array}{l}\text { University Hospital } \\
\text { of Erlangen, } \\
\text { Germany }\end{array}$ & $\begin{array}{l}\text { Treated the patient, revised the } \\
\text { manuscript, reviewed the final } \\
\text { manuscript }\end{array}$ \\
\hline
\end{tabular}


Appendix (continued)

\begin{tabular}{lll}
\hline Name & Location & Contribution \\
\hline $\begin{array}{l}\text { Roland } \\
\text { Coras, MD }\end{array}$ & $\begin{array}{l}\text { University Hospital } \\
\text { of Erlangen, } \\
\text { Germany }\end{array}$ & $\begin{array}{l}\text { Performed the neuropathology, } \\
\text { reviewed the final manuscript }\end{array}$ \\
\hline $\begin{array}{l}\text { Tobias } \\
\text { Mngelhorn, }\end{array}$ & $\begin{array}{l}\text { University Hospital } \\
\text { of Erlangen, } \\
\text { Germany }\end{array}$ & $\begin{array}{l}\text { Interpreted the CT and MRI, } \\
\text { reviewed the final manuscript }\end{array}$ \\
\hline Clara Maier & $\begin{array}{l}\text { University Hospital } \\
\text { of Erlangen, } \\
\text { Germany }\end{array}$ & $\begin{array}{l}\text { Performed the antibody tests, } \\
\text { created the figure, reviewed the } \\
\text { final manuscript }\end{array}$ \\
\hline $\begin{array}{l}\text { Matthias } \\
\text { Tenbusch }\end{array}$ & $\begin{array}{l}\text { University Hospital } \\
\text { of Erlangen, } \\
\text { Germany }\end{array}$ & $\begin{array}{l}\text { Performed the antibody } \\
\text { tests, created the figure, } \\
\text { reviewed the final } \\
\text { manuscript }\end{array}$ \\
\hline $\begin{array}{l}\text { Klaus Korn, } \\
\text { MD }\end{array}$ & $\begin{array}{l}\text { University Hospital } \\
\text { of Erlangen, } \\
\text { Germany }\end{array}$ & $\begin{array}{l}\text { Co-wrote the manuscript, } \\
\text { assisted with expertise, } \\
\text { data interpretation, and } \\
\text { discussion, reviewed } \\
\text { the final manuscript }\end{array}$ \\
\hline
\end{tabular}

Appendix (continued)

\begin{tabular}{lll}
\hline Name & Location & Contribution \\
\hline $\begin{array}{ll}\text { Armin } \\
\text { Ensser, MD }\end{array}$ & $\begin{array}{l}\text { University Hospital of } \\
\text { Erlangen, Germany }\end{array}$ & $\begin{array}{l}\text { Conceptualized case, wrote the } \\
\text { manuscript, interpreted data }\end{array}$ \\
\hline
\end{tabular}

\section{References}

1. Ng Kee Kwong KC, Mehta PR, Shukla G, Mehta AR. COVID-19, SARS and MERS: a neurological perspective. J Clin Neurosci 2020;77:13-16.

2. Corman VM, Landt O, Kaiser M, et al. Detection of 2019 novel coronavirus (2019nCoV) by real-time RT-PCR. Euro Surveill 2020;25:2000045.

3. Lapuente D, Maier C, Irrgang P, et al. Rapid response flow cytometric assay for the detection of antibody responses to SARS-CoV-2. Eur J Clin Microbiol Infect Dis Epub 2020 Oct 20 .

4. Reiber H, Lange P. Quantification of virus-specific antibodies in cerebrospinal fluid and serum: sensitive and specific detection of antibody synthesis in brain. Clin Chem 1991;37:1153-1160.

5. Baig AM, Khaleeq A, Ali U, Syeda H. Evidence of the COVID-19 virus targeting the CNS: tissue distribution, host-virus interaction, and proposed neurotropic mechanisms. ACS Chem Neurosci 2020;11:995-998.

6. Lescure FX, Bouadma L, Nguyen D, et al. Clinical and virological data of the first cases of COVID-19 in Europe: a case series. Lancet Infect Dis 2020;20:697-706.

7. Moriguchi T, Harii N, Goto J, et al. A first case of meningitis/encephalitis associated with SARS-coronavirus-2. Int J Infect Dis 2020;94:55-58.

\section{COVID-19 and Neurologic Disease: Call for Papers!}

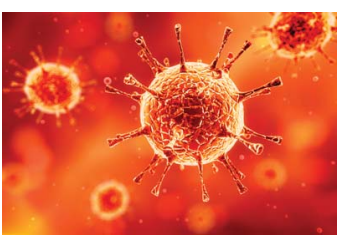

The editors of Neurology are interested in papers that address the neurological aspects of COVID-19 infection and challenges to the management of patients with chronic neurological conditions who have, or are at risk for, the infection. Relevant papers that pass initial internal review will undergo expedited peer review and online publication. We will consider papers posted in preprint servers.

Submit observational studies and clinical trials as Articles and case series and case reports under the Clinical/Scientific Notes category to https://submit.neurology.org/ today!

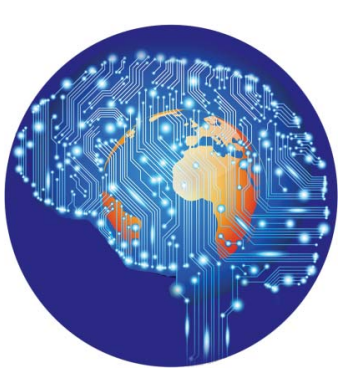

\section{Practice Current: An interactive exchange on controversial topics}

Share your own best practices.

Read commentary with expert opinion.

Explore results on an interactive world map.

NPub.org/NCP/practicecurrent

Neurology ${ }^{\circledR}$ Clinical Practice 


\section{Neurology}

\section{Pearls \& Oy-sters: SARS-CoV-2 Infection of the CNS in a Patient With Meningeosis Carcinomatosa}

Philipp A. Steininger, Frank Seifert, Stefanie Balk, et al.

Neurology 2021;96;496-499 Published Online before print December 8, 2020

DOI 10.1212/WNL.0000000000011357

\section{This information is current as of December 8, 2020}

Updated Information \&

Services

References

Subspecialty Collections

Permissions \& Licensing

Reprints including high resolution figures, can be found at: http://n.neurology.org/content/96/10/496.full

This article cites 6 articles, 1 of which you can access for free at: http://n.neurology.org/content/96/10/496.full\#ref-list-1

This article, along with others on similar topics, appears in the following collection(s):

COVID-19

http://n.neurology.org/cgi/collection/covid_19

Meningitis

http://n.neurology.org/cgi/collection/meningitis

Metastatic tumor

http://n.neurology.org/cgi/collection/metastatic_tumor

MRI

http://n.neurology.org/cgi/collection/mri

Information about reproducing this article in parts (figures,tables) or in its entirety can be found online at:

http://www.neurology.org/about/about_the_journal\#permissions

Information about ordering reprints can be found online:

http://n.neurology.org/subscribers/advertise

Neurology ${ }^{\circledR}$ is the official journal of the American Academy of Neurology. Published continuously since 1951, it is now a weekly with 48 issues per year. Copyright @ 2020 American Academy of Neurology. All rights reserved. Print ISSN: 0028-3878. Online ISSN: 1526-632X.

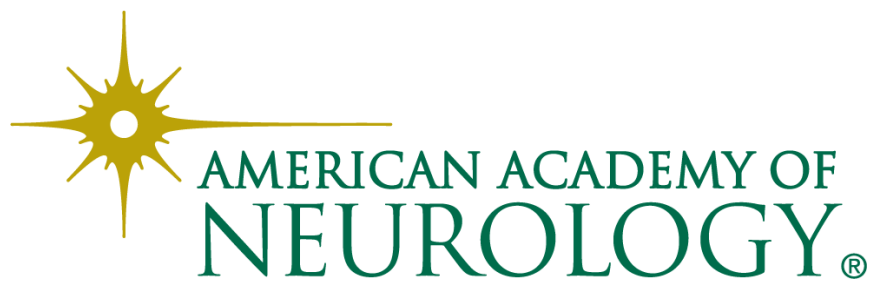

